\title{
Z historie Ústavu soudního inženýrství Vysokého učení technického v Brně - IV
}

\author{
From the History of the Institute of Forensic Engineering, \\ Brno University of Technology - Part IV
}

Albert Bradáć ${ }^{*}$, emeritní profesor

\begin{abstract}
Abstrakt
V předchozích příspěvcích jsme se zabývali počátečním obdobím vzniku ústavu, podrobněji pak rozvojem analýzy silničních dopravních nehod. Dalšími obory činnosti ústavu jsou mimo jiné stavebnictví a ekonomika - oceňování nemovitostí. Přibližme si i tuto problematiku z hlediska historie oboru obecně, rozvoje teorie a nakonec opět se zajímavými (někdy až kuriózními) př́iklady, řešenými ústavem. Jedná se opět o případy historické, k nimž již většinou není podrobná dokumentace; čtenáři jistě i zde prominou zjednodušené názorné nákresy, vyhotovené v programech, jež jsou k dispozici v MS Office - MS Word>Vložit obrazce a Malování.
\end{abstract}

Klíčová slova: znalec, znalecký posudek, znalecký ústav, výchova soudních znalců, stavebnictví, oceňování nemovitostí/nemovitých věcí.

\section{OBOR STAVEBNICTVÍ NA ÚSTAVU - ZNALECTVÍ A VÝUKA}

\subsection{Vznik a rozvoj oboru stavebnictví na Ústavu soudního inženýrství VUT v Brně}

Obor stavebnictví byl a je na ústavu řešen ve spolupráci zejména s odborníky z Fakulty stavební VUT. Jako rozhodující pro počátek výuky byla situace, kdy na žádost Českého úřadu bezpečnosti práce a České státní pojišt’ovny zajistil ústav v akademickém roce 1972/73 společně s Fakultou strojní postgraduální studium pro inspektory vyhrazených zařizení „Odborný technický dozor strojní“. Kurs se setkal se značným ohlasem u objednatelů, kteří si následně vyžádali obdobné postgraduální studium pro inspektory bezpečnosti práce a pojišt'ovací specialisty v oboru stavebnictví. První takový kurs byl zahájen v akademickém roce 1973/1974; v jeho průběhu bylo studium na žádost českého ministerstva spravedlnosti rozšířeno o problematiku oceňování nemovitostí. Toto postgraduální studium (po změně zákona o VŠ nyní jako kursy celoživotního vzdělávání, CŽV) pak pokračovalo prakticky každým rokem; v současné době je to již 51. běh. Na žádost slovenského ministerstva spravedlnosti uspořádal ústav

\begin{abstract}
In previous articles, we dealt with the initial period of the establishment of the institute, and in more detail with the development of the analysis of road traffic accidents. Other fields of activity of the institute are, among others, construction and economics - real estate valuation. Let us also approach this issue from the point of view of the history of the field in general, the development of theory and finally again with interesting (sometimes even curious) examples solved by the institute. These are again historical cases, for which there is usually no detailed documentation; readers will certainly forgive here also the simplified illustrative drawings, made in the programs available in MS Office - MS Word/Insert Shapes and Paint.
\end{abstract}

Keywords: expert, expert opinion, expert institute, education of forensic experts, construction, real estate valuation.

v letech 1980-1984 specializační studium i pro slovenské znalce (postgraduální i pomaturitní). K těmto kursům byla od počátku zajišt'ována i potřebná literatura.

\subsection{Zajímavé př́ípady oboru stavebnictví}

\subsubsection{Drolivá venkovní omítka nového bytového domu}

U jednoho z prvních posudků úkolem znaleckého ústavu v rámci posudku pro bývalou krajskou státní arbitráž bylo posoudit, proč se ve velkém drolí nová břízolitová omítka na štítové stěně nového bytového domu v Ostravě. Po shromáždění všech podkladů a místním šetření bylo ze stavebního deníku zjištěno, že tyto omítky byly prováděny koncem listopadu, $\mathrm{v}$ deníku byly uváděny teploty mezi 6 a $10^{\circ} \mathrm{C}$. Dotazem na ČHMÚ bylo ovšem zjištěno, že v daném období se teploty v místě stavby pohybovaly výrazně pod nulou, takže omítka opakovaně zamrzala a rozmrzala, tedy nebyl dodržen předepsaný technologický postup. ${ }^{1)}$

\footnotetext{
1) Tradovalo se, že za všechno může V. I. Lenin, když Velká říjnoví socialistická revoluce byla 7. listopadu 1917; bylo pak zvykem, že se tento termín dával jako socialistický závazek dokončení staveb, včetně například dálnic, a pak se neskutečně finišovalo $\mathrm{k}$ datu výročí.
} 


\subsubsection{Vlhkost v kotelně ubytovny}

Případ nové ubytovny v okresním městě, $v$ jejíž kotelně v suterénu se objevila voda, vystupující po obvodu ve styku betonové podlahy a stěn; jednalo se o spor objednatele s dodavatelem, vedený u tehdejší krajské státní arbitráže. Úkolem znaleckého ústavu bylo zjistit prŕčinu vady.

Na místě stavby s dosti vysokou hladinou podzemní vody se původně nacházela kopaná studna; tato byla zakomponována do předmětné plynové kotelny a opatřena čerpadlem s plovákovým spínačem pro udržení stálé hladiny podzemní vody pod úrovní podlahy suterénu. Odčerpaná přebytečná voda byla vedena potrubím, uloženým ve zdi, jež podle projektu mělo být ve výšce cca 1,2 m zaústěno do odbočky svislé kanalizace, uložené ve vnitřní stěně; stěny byla provedena z cihelných bloků CDK.

Studiem dokumentace nebyly zjištěny vady projektu. Po upřesnění zástupce vlastníka, že vlhkost se objevuje nejvíce u zdi, v níž je uložena svislá kanalizace, bylo přikročeno k provedení sondy odsekání zdiva u zaústění předmětného potrubí do odbočky svislé kanalizace. $\mathrm{K}$ údivu všech přítomných bylo zjištěno, že potrubí od studny končí ve zdi cca $15 \mathrm{~cm}$ před odbočkou, takže veškerá odčerpávaná voda teče př́mo do zdiva, jež má svislé dutiny, a těmi do úrovně podlahy! Mezi betonem a vodorovnou izolací pak voda prolínala k obvodu místnosti.

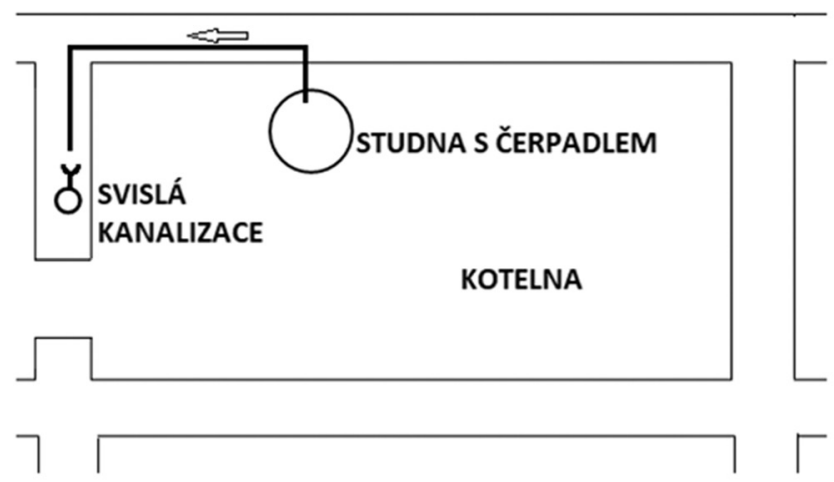

Obr. 1 K príkladu 1.2.2: Schema odvodu vody ze studny do svislé kanalizace (mistnost $v$ suterénu, bez méřitka).

Fig. 1 To example 1.2.2: Scheme of water drainage from a well to a vertical sewer (basement room, without scale).

\subsubsection{Vlhkost v suterénu bytového domu}

Př́ipad nových bytových domů v krajském městě, v jejichž technickém podlaží, částečně zapuštěném do terénu, se zejména po deštích objevovala voda; jednalo se opět o spor objednatele s dodavatelem, vedený u tehdejší krajské státní arbitráže. Úkolem znaleckého ústavu bylo zjistit př́íinu zatékání.

Byla rozpracována matice hypotéz pro stanovení všech možných př́íčin, i hypotetických. Z projektové dokumentace bylo zjištěno, že objekty byly postaveny z panelů na železobetonovou základovou desku, na niž byla provedena vodorovná izolace. Svislá hydroizolace byla rovněž vyprojektována, s ochranou cihelnou přizdívkou. Dále byla kolem celého objektu vyprojektována drenáž, uložená pod úrovní základové desky. Z celého studia projektu i stavebního deníku nevyplývala jednoznačná přícina, i když přípojky vodovodu byly instalovány do dodatečně probouraných otvorů.
Bylo proto rozhodnuto provést sondu ke zjištění skutečného provedení svislé izolace a existence či neexistence drenážního potrubí. Jaké pak bylo překvapení účastníků, když bylo zjištěno, že drenáž byla skutečně provedena, ale byla zalita betonem, údajně aby se neporušila při zasypávání!

\subsubsection{Ocelový komín elektrárny - pád montážní plošiny}

Při výstavbě nového ocelového komína elektrárny se po dosažení výšky cca 30 m zrrítili čtyři dělníci z montážní plošiny. Úkolem znaleckého ústavu bylo určit příčinu překlopení vnitřní montážní plošiny.

Komín byl budován za pomoci segmentů z ocelového plechu, stočených do tvaru poloviny válcové plochy, připravených na zemi. Po ohnutí byly plechy zajištěny $\mathrm{v}$ půlkruhovém tvaru pomocí přivařených ocelových profilů. Segmenty byly vytaženy nahoru, usazeny na spodní již hotovou část, svařeny a přivařeny ke spodní části. Práce byly prováděny z kruhové vnitřní plošiny, uložené na třech ocelových konzolách, přivařených zevnitř na předchozí vrstvě. Po dokončení vrstvy byly výše přivařeny další konzoly a plošina na ně byla vyzvednuta. Pro možnost posunu plošiny vzhůru přes přivařené konzoly byla v plošině po obvodu tři vybrání (obr. 2, jen názorné schéma, bez měřítka, konzoly v poměru k průměru plošiny zvětšeny); po vyzvednutí nad ně byla plošina pootočena.

V okamžiku havárie se plošina sklopila, zůstala jen na dvou konzolách, čtyři pracovníci se zřítili z třicetimetrové výšky, se smrtelnými následky. Pátý pracovník byl připoután bezpečnostním pásem $\mathrm{k}$ zábradlí kolem montážního otvoru uprostřed plošiny a zachránil se.

Byly zkoumány všechny $\mathrm{v}$ úvahu přicházející příčiny. Jako rozhodující se nakonec jevilo, že v projektu nebyly předepsány tolerance polotovarů - půlkruhových segmentů.

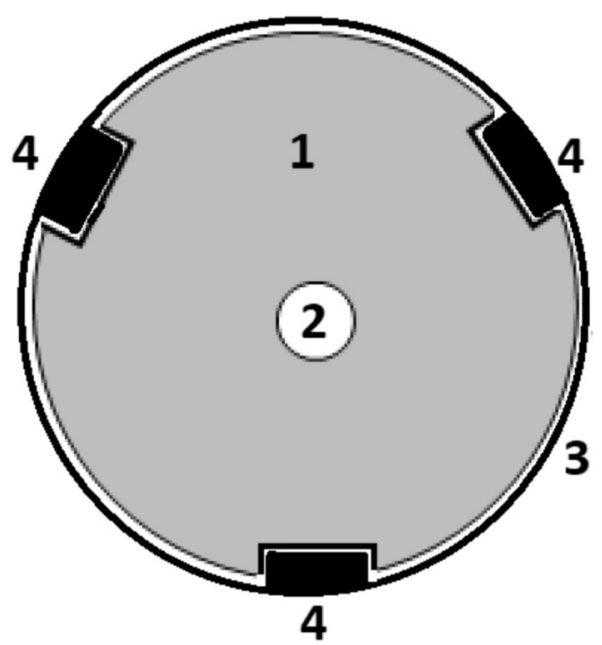

Obr. 2 K př́kladu 2.1.4: Vnitřni montážní plošina v poloze pro přesunuti výše, následuje pootočeni (schéma, pro názornost bez méř́tka). 1 -Montážni plošina - ocelový rošt; 2 Otvor pro vytahováni drobných predmětů, se zábradlím dokola; 3 - Ocelový plášt komína; 4 -Ocelové konzoly přivařené k plášti komína.

Fig. 2 To example 1.2.4: Internal mounting platform in the position for moving upwards, followed by rotation (scheme, for clarity without scale). 1 -Mounting platform - steel grate; 2 Hole for pulling out small objects, with railings all around; 3 - Steel chimney casing; 4 - Steel brackets welded to the chimney casing. 
Tyto vykazovaly odchylky v dodržení kruhovitosti, proto byly po vytažení půlkruhového segmentu nahoru před jeho přivařením přizpůsobovány rozpíráním spodní, již svařené části. Tak ovšem došlo $\mathrm{k}$ tomu, že se plošina $\mathrm{v}$ daném okamžiku prŕliš velkým rozepřením spodní části s podpěrnými konzolami dostala u jedné konzoly mimo a sklopila se. ${ }^{2)}$

\subsubsection{Závady novostavby nemocnice (porodnice-gynekologie)}

Novostavba porodnice-gynekologie v krajském městě vykazovala řadu závad, z nichž nejzávažnější, dané ke znaleckému zkoumání, byly:

- několikanásobně vyšší spotřeba tepla, než uvažoval projekt,

- problematická teplota vnitřního prostředí, výrazný rozdíl teplot na opačných koncích nemocničních postelí (až 10 stupňù),

- velmi studené podlahy v operačních sálech,

- voda dole ve výtahových šachtách, jež byla zjištěna jako infekční.

K problematice tepelně technické byly nejprve zkontrolovány původní výpočty v porovnání s projektem a bylo zjištěno, že zde prričina není. Byla tedy provedena podrobná prohlídka a sondy a bylo zjištěno:

Velkorozměrová ocelová okna v nemocničních pokojích měla oproti rámu mezery až $5 \mathrm{~mm}$, anemometr v poloze několik metrů od okna se při zavřených oknech roztočil; prritom v dané době norma připouštěla ocelová okna pouze v nejnižších podlažích. (Řešilo se ještě před posudkem zatmelením okenních spár a zákazem otevírání oken, volné zůstalo jen jedno v pokoji.)

Parapety pod okny byly $\mathrm{v}$ projektu předepsány ve skladbě (od vnitřní strany):

- cihla plná $15 \mathrm{~cm}$,

- izolace z minerální vlny,

- hliníkový plech.

Sondami bylo zjištěno, že minerální vlna není, chybělo jí asi za 8 mil. tehdejších Kčs (dodána údajně byla; šetřením policie nebylo zjištěno, kam se poděla).

Operační sály se nacházely nad otevřeným prostorem pro vstup a prríjezd sanitních vozů; na stropě tohoto prostoru měla být podle projektu nad podhledem zespodu na strop přilepena souvislá vrstva $10 \mathrm{~cm}$ pěnového polystyrenu. Sondami bylo zjištěno, že jsou zde na stropu připevněny zespodu stř̌šní latě a na nich přibity polystyrenové desky tloušt'ky pouze $2 \mathrm{~cm}$, ještě $\mathrm{k}$ tomu s mezerami mezi deskami, takže účinnost prakticky nulová. (Když autor problematiku vyprávěl studentům stavební fakulty, tak se přiznali, že toto prováděli oni v rámci tehdy obvyklé jednosemestrové praxe v prvním ročníku.)

Spodní část výtahových šachet se nacházela pod úrovní 1.NP, zapuštěná do instalačního podlaží, jež se nacházelo mezi základovou deskou a podlahou 1.NP a bylo vyplněno štěrkem. Voda byla infekční; pocházela zřejmě z kanalizace, jež byla svedena rovněž do instalačního podlaží a $\mathrm{v}$ něm vyvedena mimo

2) Nestanovení tolerance bylo orgány činnými v trestním řízení kladeno za vinu projektantům. Zajímavé bylo obvinění vedoucího projektanta, který se obhajoval tím, že nemá vysokou školu, na průmyslovce to nebrali a on má prominuté vzdělání. Bylo to ovšem klasifikováno tak, že když přijal funkci s požadovanou kvalifikací, tak si ji měl doplnit, nebo funkci nebrat.

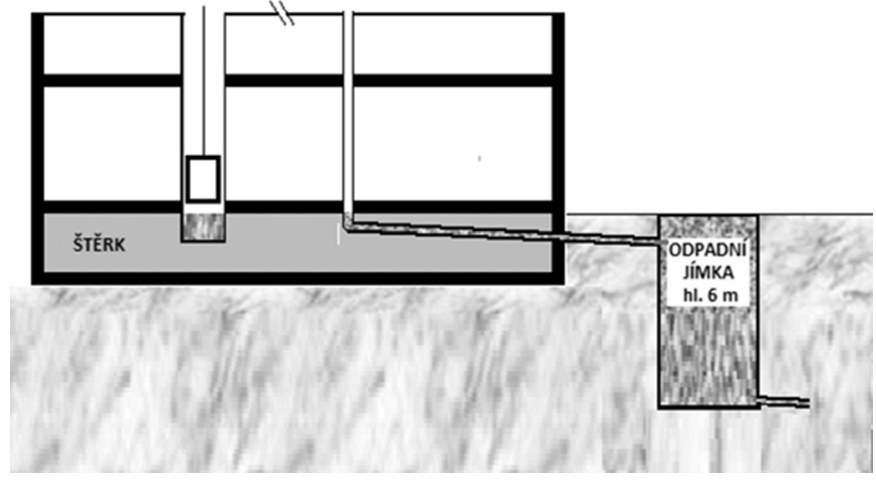

Obr. $3 \mathrm{~K}$ př́kladu 1.2.5: Uspořádání výtahových šachet, vnitřní kanalizace a odpadni jímky (zjednodušené schéma bez měřitka).

Fig. 3 To example 1.2.5: Arrangement of lift shafts, internal sewers and waste sumps (simplified diagram without scale).

objekt do odpadní jímky vedle objektu. Jímka měla podle projektu hloubku $6 \mathrm{~m}, \mathrm{z}$ její spodní části pak podle projektu vycházelo další potrubí do stoky, jež měla tyto infekční vody odvést do spalovny. Bylo přistoupeno k otevření jímky a bylo zjištěno, že je plná až po okraj; toto v návaznosti na netěsnost kanalizace v instalačním podlaží pak zřejmě způsobilo efekt spojitých nádob, kdy se hladina v jímce vyrovnala s hladinou ve výtahových šachtách.

Bylo proto přistoupeno k odkrytí zeminy nad potrubím, odvádějícím dole vody z jímky. Jaké bylo překvapení, když bylo nalezeno jen potrubí v délce jeden metr a dále nic! Situace je velmi schematicky, bez měřítka, zobrazena na obr. 3 .

(Poznámka: když autor toto dával k lepšimu při neformálni debatě o přestávce jedné zkušebni komise kursu budoucich znalců na Ústavu soudního inženýrství VUT v Brně, poznamenal pan profesor František Vavřin, že mu to pripomíná výstavbu batovských domkư ve Zlině; byla dána cena, hrazená z limitovaných investic, stavitel chtěl něco ušetřit, tak se domky postavily jen s jedním metrem potrubí, po kolaudaci se pak tiše zbytek provedl za penize z jiné kolonky, z peněz na opravy.)

\subsubsection{Opadávání opláštění zásobniků na tekutý asfalt}

Jednalo se o kruhové zásobníky na tekutý asfalt, průměru cca 15 metrů (obr. 4). Byly zhotoveny z ocelového plechu, po obvodu

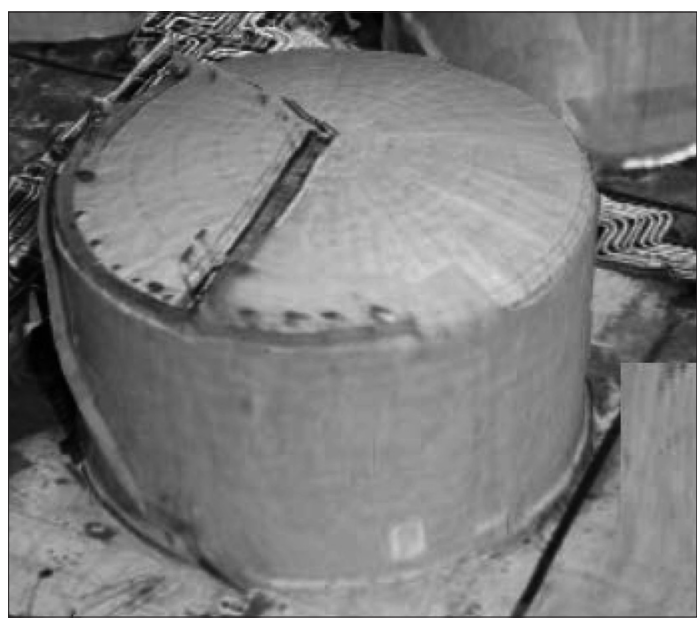

Obr. 4 K přikladu 1.2.6: Zásobnik na tekutý asfalt (ilustrační foto). Fig. 4 To example 1.2.6: Reservoir for liquid asphalt (illustrative photo). 
pak byly zvenku navařeny nastojato ocelové profily, mezi nimi tepelná izolace z minerální vlny, zakrytá dalšími plechy, přinýtovanými k ocelovým profilům. Po uvedení do provozu se krycí plechy začaly odtrhávat a při větru létaly po okolí.

Znaleckým zkoumáním bylo zjištěno, že byla opomenuta teplotní roztažnost. Vnitřní plášt' zásobníku byl ve styku s asfaltem o teplotě přes $170{ }^{\circ} \mathrm{C}$, kdežto krycí plechy byly ve styku se vzduchem kolem zásobníku. Potřebný rozdíl v délce u jednoho vnějšího plechu činí cca $3,5 \mathrm{~mm}$; poněvadž ovšem u těchto plechů s jejich roztažností nebylo počítáno, byly pevně přinýtovány, a proto došlo $\mathrm{k}$ jejich vytržení.

Dodavatel namítal, že u krycích plechů mělo dojít $\mathrm{k}$ jejich narovnání z oblouku na rovný plech; výpočtem lze ovšem zjistit, že i tak by chybělo $2,9 \mathrm{~mm}$.

\subsubsection{Praskliny opláštění tunelové sušárny v cihelně}

Novostavba teplovzdušné tunelové sušárny ve stávající cihelně, délka přes 100 metrů. Vnější plášt' podle projektu měl být kvůli teplotní roztažnosti tvořen svislými I-profily a mezi nimi volně vloženými tvárnicemi Hurdis s kolmými čely. Dilatační celky měly být podle projektu odděleny dilatační spárou, jež měla být vyplněna minerální vlnou.

Po uvedení sušárny do provozu (vnitřní teplota sušárny cca mezi 100 a $200{ }^{\circ} \mathrm{C}$ ) došlo k popraskání Hurdis tvárnic vnějšího pláště trhlinami prakticky po celé délce i výšce. Jako možná př́íčina bylo uvažováno napětí, vznikající teplotní roztažností; tomu však mělo zabránit volné uložení Hurdis tvárnic do I-profilů a dilatační spáry. Problém se vyřešil po prostudování stavebního deníku; při stavbě se nepodařilo zajistit tvárnice Hurdis s kolmými čely, projektant

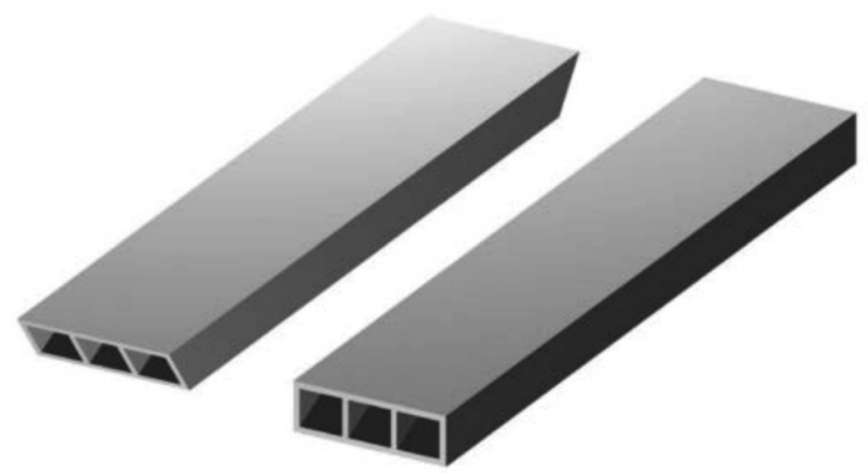

Obr. 5 K př́kladu 1.2.7: keramické tvárnice Hurdis se šikmým a s kolmým čelem.

Fig. 5 To example 1.2.7: Hurdis ceramic blocks with oblique and perpendicular faces.
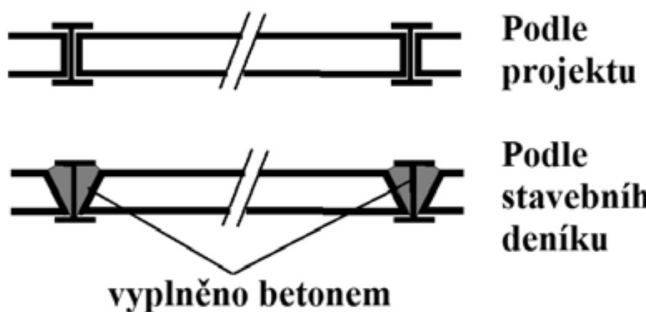

Podle stavebního deníku

Obr. 6 K príkladu 1.2.7: uložení tvárnic Hurdis do svislých I-profilů (schéma bez mérítka).

Fig. 6 To example 1.2.7: placing Hurdis blocks in vertical I-profiles (diagram without scale). proto zápisem ve stavebním deníku povolil tvárnice se šikmými čely. Aby nevypadávaly z I-profilů, zakreslil, jak je do I-profilů upevnit betonem (obr. 6). Dále pak bylo zjištěno, že v dilatační spáře zůstaly dřevěné desky z doby stavby, poněvadž se nepodařilo je odstranit a nahradit minerální vlnou.

\subsubsection{Voda v půdním prostoru výrobního objektu}

Jednalo se o nový vícepodlažní objekt tkalcovny. Stropy jednotlivých podlaží byly ocelové príhradové výšky $3 \mathrm{~m}, \mathrm{v}$ nich byla mj. vedena vzduchotechnika pro odsávání v podlahách tkalcovských dílen. Střecha nízká sedlová, krytina plechová. Pod krytinou byl volný prostor, na jehož podlaze byla vrstva izolace z minerální vlny. Problémem byla voda, srážející se na plechové krytině a odkapávající na izolaci.

Při místním šetření byli účastníci zavedeni do posledního podlaží, z něhož byl jen průlezný čtvercový otvor do půdního prostoru. Poklop otvoru byl otevřený; na dotaz sdělili zástupci vlastníka, že otvor je otevřený trvale, aby bylo možno půdní prostor kontrolovat. Bylo doporučeno, aby byl otvor zavírán, aby se teplý vzduch z horních vrstev výrobního podlaží, s vysokou relativní vlhkostí, nemohl dostávat do chladnějšího půdního prostoru a $\mathrm{k}$ chladné krytině.

\subsubsection{Výbuch ubytovny}

Ve čtvrtek 13. prosince 1973 asi ve 3:15 hodin ráno si šel předseda okresního soudu v Tachově na balkon zakouřit. Př́ímo před jeho očima došlo $\mathrm{k}$ výbuchu ubytovny národního podniku Plastimat. Při neštěstí zahynulo 47 osob, zraněno bylo sedmnáct. Jiné zdroje však udávají až 50 smrtelně zraněných. ${ }^{3)}$

Při vyšetřování bylo zjištěno, že malý výbuch nastal i v suterénu blízkého bytového domu, napojeného teplovodním potrubím na stejnou plynovou kotelnu. Do kotelny byl plyn přiváděn středotlakým potrubím.

Plynové potrubí a teplovodní kanál u kotelny vedly souběžně s kanalizací, jež byla vybudována jako poslední. Při ohledání bylo mj. zjišt'ováno, v jakém stavu se plynové potrubí nachází. Po odkrytí zeminy bylo zjištěno, že uzavírací litinové šoupátko plynového potrubí má u př́ruby prasklinu, kterou plyn uniká, Zemina nad ním byla zamrzlá, takže zde byly úvahy, že se plyn zeminou dostal do teplovodního kanálu, kterým pak proudil do objektů v okolí. Jednalo se o svítiplyn, jenž bylo také jako nízkotlak zaveden z redukční stanice do objektu ubytovny, kde byly dva plynoměry - jeden pro byt správce a druhý pro kuchyňky v ubytovací části. Plynoměry byly po havárii prasklé, proto zde byla také domněnka, že nepracovala řádně redukční stanice ze středotlaku na nízkotlak, ve které je sice na nízkotlakém potrubí U-trubice s vodním sloupcem jako pojistka proti zvýšení tlaku, která ovšem mohla být zamrzlá. Funkci redukční stanice se nepodařilo ověřit, záznamy se nepodařilo zajistit.

Pitvou obětí z horních podlaží ubytovny byla zjištěna smrtelná dávka karbonylhemoglobinu ( $\mathrm{COHb}$, také karboxyhemoglobin), jenž vzniká vazbou oxidu uhelnatého (zde ze svítiplynu)

3) Co do počtu zemřelých patří toto neštěstí k nejhorším z těch, $\mathrm{k}$ nimž po druhé světové válce došlo na území bývalého Československa. Na stejném místě byla později postavena nová ubytovna, již bez připojení na plyn. V ní 18. srpna 2016 vypukl požár, při kterém muselo být evakuováno více než 100 lidí. Blíže viz: https://cs.m.wikipedia.org/wiki/Výbuch_ubytovny_v_Tachově. 
na hemoglobin 4); bylo tedy zřejmé, že oběti směs plynů s $\mathrm{CO}$ nějakou dobu před smrtí dýchaly.

V rámci pátrání po zdroji svítiplynu bylo mj. odkryto potrubí středotlaku, přivádějící plyn do kotelny.

Jal výše uvedeno, před kotelnou bylo na potrubí instalováno litinové šoupátko, u kterého byla zjištěna prasklina u př́ruby. Potrubí bylo u šoupátka uloženo na cihelných sloupcích. Jako poslední byla budována kanalizace, jejíž potrubí bylo uloženo do dodatečně provedeného výkopu, níže než potrubí plynové; přitom se údajně stěny výkopu sesouvaly. Vyšetřovatel pak obvinil mistra a stavbyvedoucího firmy, provádějící předmětnou kanalizaci, že špatně zajištěným výkopem způsobili prasknutí šoupátka, ze kterého pak unikal svítiplyn, jenž se pod zmrzlou zeminou dostal do topného kanálu a tímto kanálem pak do objektu bytového domu a ubytovny.

Otázkou zde byl také důvod resp. způsob iniciace výbuchu $\mathrm{v}$ dané noční době.

Mistr a stavbyvedoucí byli v prvním stupni odsouzeni k nepodmíněným trestům, Následovalo odvolání; odvolací soud si vyžádal, aby znalecký ústav stanovil příčinu výbuchu, a pokud nebude možno stanovit ji jednoznačně, požadoval neobvykle, aby byly vyjmenovány všechny v úvahu přicházející př́ičiny a u každé byla stanovena její pravděpodobnost $\mathrm{z}$ technického hlediska.
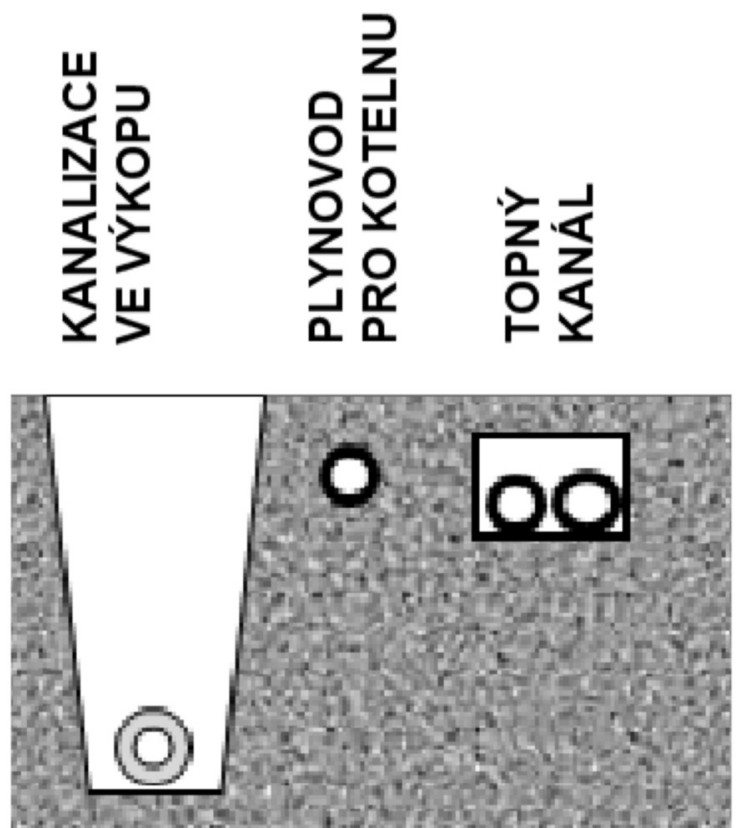

Obr. 7 K př́kladu č. 1.2.9: Nákres rozložení jednotlivých potrubi u středotlaké kotelny - př́ičný řez (bez měritka)

Fig. 7 For example No. 1.2.9: Drawing of the layout of individual pipes at a medium-pressure boiler room-cross section (no scale).

4) Oxid uhelnatý (CO) vzniká při nedostatečném spalování uhlíku a organických sloučenin (napr. fosilních paliv); je obsažen ve výfukových plynech, v kouři při nedostatečně táhnoucím komínu, v cigaretovém kouři, v sopečném kouři. Dále je součástí svítiplynu, generátorového plynu a vodního plynu, v nízké míře vzniká v atmosféře fotolýzou oxidu uhličitého a v nepatrných koncentracích je vydechován z plic. Váže se na hemoglobin stejným mechanismem jako kyslík. Problémem však je jeho afinita, která je přibližně $250 \times$ vyšší, než je tomu u molekuly kyslíku, což znamená, že se váže již ve velmi nízkých koncentracích. (http://patf-biokyb.lf1.cuni.cz/ wiki/vyuka/otrava_oxidem_uhelnatym).

\section{OBOR EKONOMIKA - OCEŇOVÁNÍ NEMOVITOSTÍ}

\subsection{Vznik a rozvoj oboru na ÚSI}

Jak bylo výše uvedeno, první kurs oboru stavebnictví byl zahájen v akademickém roce 1973/1974; v jeho průběhu bylo studium na žádost českého ministerstva spravedlnosti rozšířeno o problematiku oceňování nemovitostí, kterou zajišt'oval tým odborníků sestavený ministerstvem (tzv. „Vacura boys": JUDr. Jiří Vacura z Ministerstva spravedlnosti, referent problematiky znalectví, předmět Práva a povinnosti znalců, JUDr. Jiří Mikeš rovněž z MSp (Základy občanského práva), dále dlouholetý znalec a autor publikací Ing. Miloslav Skácelík (Oceňování staveb ve stopcenách), Ing. arch. Zdeněk Horniecký, CSc. z VÚVA (Oceňování staveb v osobním vlastnictví), JUDr. Gustav Pickart z Min. financí (Nemovitosti a socialistické vlastnictví). V dalších kursech pak postupně problematiku přebírali odborníci z VUT resp. ÚSI

V prvních kursech byla metodika oceňování nemovitostí ovlivněna tehdy platným občanským zákoníkem, podle kterého občan nemohl prodat nemovitost za cenu vyšší než stanovenou podle předpisu; pokud by byla sjednána cena vyšší, pak byla smlouva od počátku neplatná, a pokud se připojil do řízení i prokurátor, mohla propadnout státu nemovitost i sjednaná částka. Jako př́klad aplikace tohoto ustanovení může sloužit př́ípad, kdy občan prodal garáž jinému občanovi a následně prodávající emigroval. Prokurátor žaloval kupujícího o vydání garáže, protože smlouva byla sjednána s vědomím toho, že prodávající bude emigrovat a garáž by propadla státu. Kupec složitě u soudu zdůvodnil, že kupce předtím neznal, že garáž koupil na inzerát. Soud žalobu zamítl; kupec si povzdychl, že je to dobře, že by přišel o 24000 Kčs. Odhad i smlouva byly ale jen na 7000 Kčs; povzdech ovšem zaslechl prokurátor, naznal, že vědomě byl porušen zákon a garáž nakonec přece jen státu propadla.

\subsection{Období oceňování staveb podle třídy kvality (1. 5. 1964 až 31. 12. 1984)}

\subsubsection{Metodika trídy kvality}

Metodika náhradové vyhlášky č. 18/1963 Sb., dále pak vyhlášky č. 73/1964 Sb. a následně č. 43/1969 Sb. určovala cenu alespoň přibližně odpovídající reprodukčním nákladům jen u staveb v osobním vlastnictví (rodinné domy, rekreační chaty, individuální garáže a jejich příslušenství); u staveb v soukromém vlastnictví (hlavně nájemní domy resp. provozovny s ev. bytem, nesplňující podmínku bytového domu $2 / 3$ podlahové plochy na byty) byly například náhrady při vyvlastnění velmi nízké, v počátcích 20 až 30 haléřů, u vyhlášky č. 43/1969 Sb. pak 4,- až 6,- Kčs za 1 m³ , bez ohledu na stav a stáríi.

Aby se předcházelo spekulacím, nemohly se mezi občany prodávat nezastavěné stavební pozemky; pro pozemky zastavěné platila podle $\S 14$ vyhl. č. 43/1969 Sb. cena ve výši 4,- až 15,- Kčs/ $\mathrm{m}^{2}$ (podle velikosti obce). Pro jiné pozemky (např. zemědělské) platila sazba $0,40 \mathrm{Kčs} / \mathrm{m}^{2}$. Pokud chtěl občan stavět, mohl dostat od státu pozemek do tzv. osobního užívání (pro rodinný dům výměru max. $800 \mathrm{~m}^{2}$, pro chatu resp. zahradu max. $400 \mathrm{~m}^{2}$, pro garáž jen nutnou výměru). Obcházelo se to tím, že se začalo stavět na jméno vlastníka pozemku a teprve až byla stavba rozestavěna, došlo k převodu; kvůli tomu se vyvinula judikatura do stavu, že 
stavba jako věc začíná existovat, je-li zdivo 1. nadzemního podlaži natolik hotovo, že je zřetelná jeho dispozice, zpravidla min. jeden metr výšky zdiva.

Rodinné domy v osobním vlastnictví (a obytné části zemědělských usedlostí) se oceňovaly podle obytné plochy (pokoje od $8 \mathrm{~m}^{2}$ a u kuchyně výměra nad $12 \mathrm{~m}^{2}$, garáže a jednou polovinou neobytné místnosti, např́iklad komory resp. pokoje pod $8 \mathrm{~m}^{2}$ ) výchozí cenou podle tř́́dy kvality:

třída I za $1 \mathrm{~m}^{2} \quad$ Kčs $3280,-$

tř́da II Kčs 2350,-

třída III Kčs 1720,-

tř́ida IV Kčs 1370,-

Kritéria pro zařazení do jednotlivých tříd jsou uvedena za př́lohou vyhlášky (zde tab. 1). Problémem bylo, že nebylo možno mezi třídami interpolovat a přitom některé znaky neměly popisy jednoznačné, takže to bylo bud' jedna trrída nebo druhá; některé se naopak vyskytovaly ve více třídách. Přitom rozdíly mezi třídami byly velké - např́klad při $120 \mathrm{~m}^{2}$ obytné plochy byla cena nového objektu $120 \times 3280,-=393600$ Kčs, u druhé třídy 282000 Kčs, rozdíl tedy 111600 Kčs, což je 40 \% při základu ceny z II. třídy. Tabulka přitom zřejmě byla odvozena z tabulek, vytvořených kolem roku 1939 pro účely stanovení tzv. stopcen, tedy pro stavby poplatné tehdejšímu vybavení, takže pozdější materiály a vybavení v ní nebyly obsaženy. K tomuto pak byly postupně vydávány vysvětlivky; např́klad znak 7 podlahy neobsahoval podlahoviny typu Kovral (podle vysvětlivek I. třída), Jekor (II. třída), PVC ap. Pokud znak nebyl, zařadil se do IV. třídy. Také bylo důležité, aby vybavení bylo součástí stavby (tedy s ní pevně spojeno), nikoliv př́slušenstvím.

Od takto stanovené ceny stavby se odečetlo opotřebení podle ustanovení $\S 2$ odst. 3 a 4 :

„Cena rodinného domku se přiměřeně sniži o jeho opotřebení; toto snižení čini zpravidla při běžné údržbě $1 \%$ za každý rok stář stavby. U rodinného domku, na němž byla provedena modernizace nebo generální oprava, je snižení přiměreně nižši a u rodinného domku, u něhož údržba nebo opravy byly zanedbány, nebo jde-li o rodinný domek poškozený, prriměreně vyšší. Pro posouzeni stář rodinného domku je při pochybnostech rozhodujici datum uvedeni stavby do uživání."

Problém zde v době, kdy se často stíhalo za trestný čin „Rozkrádání majetku v socialistickém vlastnictví“, činil výklad použití slova „zpravidla“, tedy zda je možno zohlednit i lepší stav objektu, než vychází mechanickým použitím jednoho procenta ročně, když nebyla provedena modernizace nebo generální oprava. Při stanovení náhrady při vyvlastnění staveb v osobním vlastnictví platilo podle $\S 12$ odst. 2 , že snížení z důvodu stáŕí stavby činí u rodinného domku a obytné části zemědělské usedlosti nejvýše $70 \%$, u dalších staveb pak nejvýše $80 \%$. Obdobná ustanovení pak byla použita i v novějších předpisech.

Pozemky mezi občany se převáděly za cenu z roku 1939 (tzv. stopceny) až do roku 1979, kdy byl vydán výměr č. 120/47/79 o cenách pozemků, kterým se stanovily nejvyšší možné ceny pozemků, nabývaných od občanů nebo jiných než socialistických organizací (např. církví) občany nebo jinými než socialistickými organizacemi; v zastavěném území obce podle velikosti obce 4,až $15,-$ Kčs $/ \mathrm{m}^{2}$, obdobně zastavěné plochy s nádvořím a zahrady mimo zastavěné území obce patřící $\mathrm{k}$ rodinnému domku nebo k zemědělské usedlosti, pozemek mimo zastavěné území obce určený pro stavbu rekreační chaty nebo na zřízení zahrádky anebo pozemek již k tomuto účelu použitý a pozemek určený pro stavbu rodinného domku. Za jiné pozemky pak $0,40 \mathrm{Kčs} / \mathrm{m}^{2}$.

V § 10 pak bylo stanoveno, že ceny staveb v osobním vlastnictví, jakož i staveb prodávaných socialistickými nebo jinými organizacemi občanům do osobního vlastnictví mimo rámec obvyklého hospodaření, byly cenami nejvyššími; nabyl-li ovšem vlastník stavbu v osobním vlastnictví po 1. červnu 1953 za cenu vyšší než stanovenou podle vyhlášky, byly nejvyšší cenou prokazatelné nabývací náklady po odečtení opotřebení podle vyhlášky (používáno zejména při výkupech pro účely přehrad apod.).

\subsubsection{Příklad problému při ocenění RD podle tř́dy kvality}

Př́ikladem uvedených problémů může být případ z okresního města, kde si dva mladí manželé postavili rodinný dům, nějakou dobu nato emigrovali a dům propadl státu. Dům byl po delší době za cenu stanovenou znalcem podle II. třídy kvality prodán řediteli významného místního podniku. Původní majitelé se po roce 1989 vrátili a žádali vydání. Podmínkou podle zákona č. 87/1991 Sb., o mimosoudních rehabilitacích bylo, že nemovitost byla současnému majiteli prodána pod cenou, nebo že kupující byl neoprávněně zvýhodněn ${ }^{5)}$. Původní majitelé si nechali vypracovat znalecký posudek, kolik měl dům správně stát, a tento znalec dům odhadl v I. trrídě kvality, tedy že měl stát podstatně více. Přitom mj. zařadil znak č. 7 podlahy do I. třídy, poněvadž zde ve všech obytných místnostech byly koberce Kovral.

Při ohledání v rámci revizního posudku bylo ovšem zjištěno, že koberce Kovral jsou jen volně položeny, nikoliv přilepeny $\mathrm{k}$ betonovému podkladu. Nebyly tedy součástí domu, ale jen příslušenstvím. Nový vlastník prokázal stvrzenkou, že koberce koupil zvlášt' přes Bazar Klenoty jako samostatné věci; nebyly tedy součástí stavby, znak se pak zařadil do IV. třídy, následně zůstalo v I. trrídě jen 13 znaků (méně než $2 / 3$ z 21, vážený průměr byl nad $1,33^{6)}$ a objekt se zařadil do II. trrídy. ${ }^{7)}$

\subsubsection{Př́klad - ocenění RD po rozsáhlé rekonstrukci podle tř́dy kvality}

Jiným odstrašujícím prríkladem ${ }^{8)}$ bylo ocenění vily národního umělce, který ji po rozsáhlé rekonstrukci prodával socialistické

\footnotetext{
5) Podle $\S 4$ odst. 2 „Povinnými osobami jsou též fyzické osoby, jež nabyly věc od státu, ..., a to $\mathrm{v}$ př́ípadech, kdy tyto osoby nabyly věc bud' v rozporu s tehdy platnými předpisy, nebo na základě protiprávního zvýhodnění osoby nabyvatele, dále i osoby blízké těchto osob, pokud na ně věc byla těmito osobami převedena.

6) I při nejpříznívějším stavu, pokud nebylo dosaženo dvou třetin znaků v I. třídě, nebylo možno stavbu váženým průměrem zařadit do I. trrídy: $(13 \times 1+8 \times 2) / 21=1,38$, tedy II. trí́da.

7) Zde jedna kuriozita: původní vlastníci tvrdili, že když opouštěli republiku, Kovraly byly přilepené. Na dotaz, čím byly přilepeny sdělili, že lepidlem na tapety. Následně bylo zjištěno, že dům byl delší dobu neobýván, zamrzla voda v topení, toto prasklo a po oteplení voda vytekla do pokojů, koberce se odlepily. Není také jasné, jak probíhal úklid po této události; objekt měl celou tuto dobu v péči finanční odbor ONV.

8) Poznámka autora: $z$ textu by se mohlo zdát, že co znalec to podvodník; je však třeba vzít v úvahu, že na znalecký ústav se dostávaly převážně vadné posudky. Ze statistiky Ministerstva spravedlnosti za rok 2015 např́íklad vyplývá, že bylo celkem 9193 znalců - fyzických osob, celkem 251267 znaleckých posudků, přitom jen 34 pokuty a 5 výstrah. Počty trestaných za nepravdivé znalecké posudky se nepodařilo ve veřejně dostupných databázích zjistit, jeví se, že nejsou zvlášt' sledovány.
} 
Tab. 1 Př́loha č. 1 k vyhlášce č. 43/1969 Sb.

Tab. 1 Annex No. 1 to Decree No. 43/1969 Coll.

Zařazení rodinných domků a obytných částí zemědělských usedlostí podle kvality do 4 tř́íd

\begin{tabular}{|c|c|c|c|c|}
\hline Třída & I & II & III & IV \\
\hline 1. zdivo & cihelné masivní & $\begin{array}{l}\text { s dostatečnou izolační } \\
\text { schopností, sruby dřevěné }\end{array}$ & $\begin{array}{l}\text { zdivo různé, kombinované } \\
\text { i s dřevem }\end{array}$ & nepálená cihla, kámen \\
\hline 2. fasáda & $\begin{array}{l}\text { obložená i částečně } \\
\text { tvrdá omítka }\end{array}$ & $\begin{array}{l}\text { břizolitová omítka, } \\
\text { režné zdivo lícové }\end{array}$ & $\begin{array}{l}\text { vápenná štuková omítka, } \\
\text { stř́íkaný břizolit }\end{array}$ & vápenná štuková \\
\hline 3. střecha & $\begin{array}{l}\text { plochá plechová, asfaltová, } \\
\text { dvojitá tašková, prejzy, } \\
\text { esovky, šamotová dlažba } \\
\text { na terasách }\end{array}$ & $\begin{array}{l}\text { plochá preskies, dvojité tašky, } \\
\text { terasy, cementové dlaždice }\end{array}$ & $\begin{array}{l}\text { plochá lepenková, dvojité } \\
\text { tašky }\end{array}$ & $\begin{array}{l}\text { plochá jednoduchá } \\
\text { lepenka, jednoduchá } \\
\text { tašková }\end{array}$ \\
\hline 4. schodiště & $\begin{array}{l}\text { obložené, žula částečně } \\
\text { leštěná, zábradlí z nerezu }\end{array}$ & $\begin{array}{l}\text { žula neleštěná, dobré teraco, } \\
\text { dřevo měkké, truhlářsky } \\
\text { zpracované }\end{array}$ & $\begin{array}{l}\text { horší žula, teracové stupně, } \\
\text { pískovec, dřevo měkké }\end{array}$ & $\begin{array}{l}\text { beton, dřevo tesařsky } \\
\text { zpracované bez } \\
\text { podstupnic }\end{array}$ \\
\hline 5. izolace & $\begin{array}{l}\text { vodotěsné, tepelné } \\
\text { a proti hluku }\end{array}$ & vodotěsné & zdí proti zemní vlhkosti & $\begin{array}{l}\text { bez izolací proti zemní } \\
\text { vlhkosti }\end{array}$ \\
\hline 6. zárubně & ocelové, dřevem obložené & ocelové a truhlářské rámky & obíjené & hrubé \\
\hline 7. podlahy & $\begin{array}{l}\text { vlýskové, parketové, korek, } \\
\text { linoleum }\end{array}$ & vlysy bukové & palubové & prkenné \\
\hline 8. dlažby & šamotové, linoleum, guma & xylolit, teraco & cement, dlaždice & cihly nebo mlat \\
\hline 9. vytápění & $\begin{array}{l}\text { radiátory na vodu, } \\
\text { teplovzdušné komůrky }\end{array}$ & $\begin{array}{l}\text { americká nebo dobrá kachlová } \\
\text { kamna }\end{array}$ & $\begin{array}{l}\text { kachlová jednoduchá nebo } \\
\text { železná kamna }\end{array}$ & $\begin{array}{l}\text { kamna obyčejná, } \\
\text { bubínky, pec }\end{array}$ \\
\hline 10. kuchyně & $\begin{array}{l}\text { elektrický nebo plynový } \\
\text { sporák, dřez na teplou } \\
\text { a studenou vodu }\end{array}$ & $\begin{array}{l}\text { kachlové nebo smaltované } \\
\text { sporáky - dřez na studenou } \\
\text { vodu }\end{array}$ & $\begin{array}{l}\text { kachlové jednotroubové } \\
\text { sporáky, výlevka }\end{array}$ & cihelné sporáky \\
\hline $\begin{array}{l}\text { 11. příprava } \\
\text { teplé vody }\end{array}$ & $\begin{array}{l}\text { teplá voda z karmy, bojleru } \\
\text { pro kuchyň i lázeň }\end{array}$ & teplá voda z karmy jen v lázni & $\begin{array}{l}\text { koupelnová kamna } \\
\text { na uhlí }\end{array}$ & $\begin{array}{l}\text { bez př́ípravy } \\
\text { teplé vody }\end{array}$ \\
\hline 12. lázeň & $\begin{array}{l}\text { vana obložená } 150 \mathrm{~cm} \text {, } \\
\text { umývadlo a bidet - šamotová } \\
\text { dlažba }\end{array}$ & $\begin{array}{l}\text { volně stojící vana smaltovaná, } \\
\text { jen částečně obkládačky, } \\
\text { teracová dlažba }\end{array}$ & $\begin{array}{l}\text { plechová vana zinková, } \\
\text { betonová dlažba, olejový nátěr } \\
\text { stěn }\end{array}$ & - \\
\hline 13. záchod & $\begin{array}{l}\text { splachovací, obložený, } \\
\text { šamotová dlažba }\end{array}$ & $\begin{array}{l}\text { splachovací, dlažba šamotová, } \\
\text { teraco, bez obkladu }\end{array}$ & splachovací, betonová dlažba & nesplachovací \\
\hline 14. voda & $\begin{array}{l}\text { teplá a studená } \\
\text { v koupelně, kuchyni }\end{array}$ & $\begin{array}{l}\text { teplá v koupelně - zdroj } \\
\text { plynový, elektrický }\end{array}$ & $\begin{array}{l}\text { teplá z koupelnových kamen } \\
\text { na uhlí }\end{array}$ & - \\
\hline $\begin{array}{l}\text { 15. elektrické } \\
\text { instalace }\end{array}$ & $\begin{array}{l}\text { moderní zásuvky, zvonky, } \\
\text { elektroměr mimo byt }\end{array}$ & v trubkách & navrch & provizorní \\
\hline 16. okna & dvojitá & dvojitá nebo zdvojená & zdvojená & jednoduchá \\
\hline 17. dveře & $\begin{array}{l}\text { překližované, zámky } \\
\text { s vložkami nebo dozické }\end{array}$ & $\begin{array}{l}\text { překližované a náplňové } \\
\text { s obyčejnými zámky }\end{array}$ & náplňové s obyčejnými zámky & $\begin{array}{l}\text { náplňové, visací zámky, } \\
\text { závlačky }\end{array}$ \\
\hline 18. prádelna & $\begin{array}{l}\text { v domě s pračkou, kotlem, } \\
\text { necky, stůl, vytápění }\end{array}$ & v domě, kotel malý & $\mathrm{v}$ domě bez kotle & - \\
\hline 19. sušárna & vytápěná nebo půda & nevytápěná nebo půda & půda & - \\
\hline 20. sklep & $\begin{array}{l}\text { na palivo } \\
\text { nebo v domě sklad }\end{array}$ & sklad v domě & $\begin{array}{l}\text { sklep nebo kolnička mimo } \\
\text { objekt }\end{array}$ & mimo objekt \\
\hline $\begin{array}{l}\text { 21. vestavěná } \\
\text { garáž }\end{array}$ & $\begin{array}{l}\text { vytápěná s elektrickým } \\
\text { osvětlením }\end{array}$ & elektricky osvětlená & jednoduchá & - \\
\hline \multicolumn{5}{|c|}{ 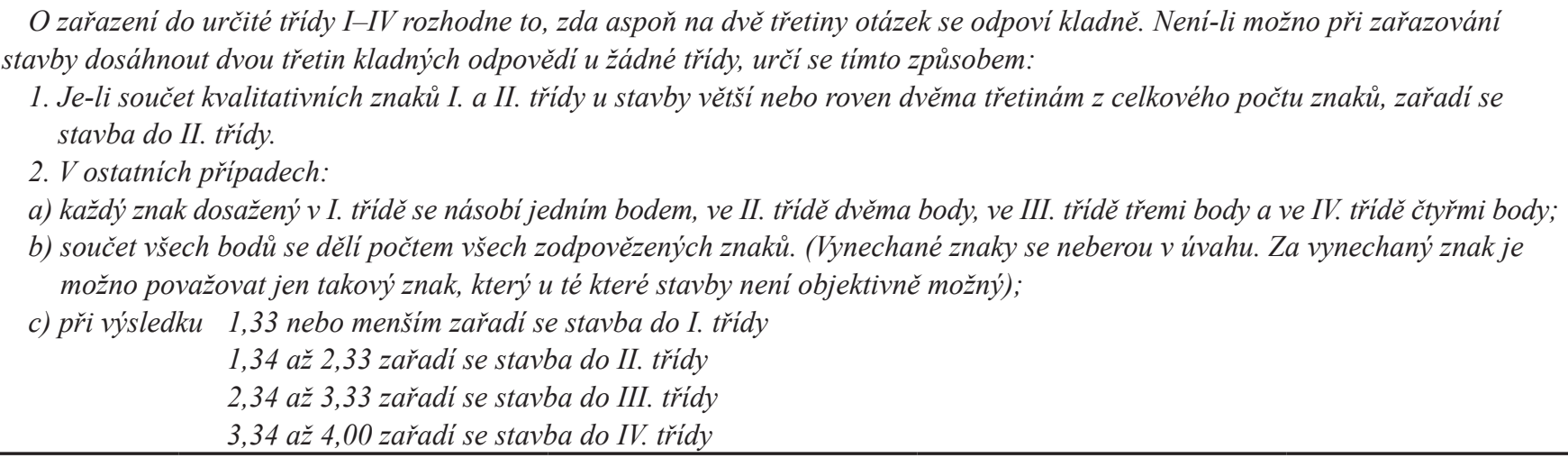 } \\
\hline
\end{tabular}


organizaci. Znalec, nedávno bez speciálního vzdělání protekčně jmenovaný ministrem spravedlnosti, ji ocenil podle vyhlášky č. 43/1969 Sb. na cca jeden milion korun. Následně připočetl cenu oprav podle předloženého rozpočtu rekonstrukce, jenž byl ve výši cca pět milionů; takový součet ovšem nebyl pro ocenění možný, vyhláška jej neumožňovala, stanovila konečnou cenu stavby při stavu k datu ocenění. (Poznámka: tento postup většinou není možný ani dnes, rekonstrukce zahrnuje zpravidla i cenu demoličních prací, odvoz a uložení materiálu z demolice, cenu ztížené práce v hotové stavbě apod.). V rámci následného řízení revizní znalci určili cenu kolem milionu, stejně jako následně i ústav.

V rámci tohoto posudku byl ústavem překontrolován i původnímu znalci předložený rozpočet rekonstrukce. Byly zjištěny podstatné rozdíly ve výměrách, např́klad když se sečetly všechny projektované výměry mramorových podlah, tak by to znamenalo mramor ve všech místnostech do výše 0,6 metru. Z tohoto posudku i z dalších byly zjištěny časté chyby, jichž se znalci dopouštěli, např́iklad:

- nezkontrolování předloženého rozpočtu,

- záměna krytiny pálené a červené betonové (i když v daném př́padě ještě část nové byla na zahradě u vily),

- záměna plechových krytin z plechu ocelového pozinkovaného, z titanzinku resp. hliníkového (jednou dokonce byly ještě zbytky od klempiřru v objektu),

- nezměření skutečné hloubky kopané studny, převzetí sdělené hloubky bez kontroly změřením,

- u kubatury odpadní jímky převzata hodnota sdělená objednatelem, bez prověření, rozdíl i několikanásobek objemu.

Původní znalec byl za nepravdivý posudek odsouzen k odnětí svobody nepodmíněně $v$ délce jednoho roku. Po nějakém čase se přihlásil do studia na ústavu; zajímavé pak byly jeho postřehy $\mathrm{z}$ vězení...

\subsubsection{Problém s podvodem při ocenění areálu před předpokládanou demolicí}

Další př́ípad, kdy si znalec způsobil problémy. Malá obec na severni Moravě se domluvila s majitelem usedlosti o jejím odkoupení s tím, že bude zbourána a na jejím místě obec postaví kulturní dům. Cena za areál byla sjednána na tehdejších 300000 Kč; až potom byl objednán znalecký posudek, s požadavkem na znalce, aby to vyšlo na dohodnutou částku. Znalec (vedoucí odboru výstavby ONV) areál ocenil správně, ale k uvedené ceně nedosáhl. Přidal k tomu tedy smyšlenou neexistující garáž; předpokládal, že se areál odstraní a nebude možná kontrola. Obec však neměla v dané době na demolici finance, areál zůstal v původním stavu, až došlo na udání a trestní řízení. Přri zhlédnutí místa vyšetřovatel garáž nenašel; znalce večer po př́ijezdu ze služební cesty zadrželi a on přiznal, že za posudek dokonce dostal od prodávajícího úplatek 20000 Kčs. Ráno už tvrdil, že to byla jen půjčka. Vyšetřovatel dále zabavil kopie jeho posudků a požádal ústav, aby zhodnotil u posudků pro poplatky $\mathrm{z}$ dědictví, resp. $\mathrm{v}$ případech, kdy prodával stát, zda není opotřebení staveb nápadně vysoké, resp. když kupoval stát, naopak př́liš nízké.

\subsubsection{Př́klad jiného problému při ocenění RD před předpokládanou demolicí}

Jiný př́iklad pochybení znalce, tentokrát v Praze. Pro výstavbu v novém sídlišti se kvůli předpokládanému hluku z projektovaného silničního průtahu vykupovaly rodinné domy, jež byly př́liš blízko budoucí komunikace. Inkriminovaný dům byl při ocenění zařazen do II. třídy kvality. Vlastník původně s výkupem nesouhlasil, s tím, že mu hluk nebude vadit. Když později o výkup přece jen požádal, bylo mu doporučeno, aby si nechal sám zhotovit znalecký posudek. Jím zvolený znalec po prohlídce objektu konstatoval, že do I. třídy kvality chybí jeden znak do $2 / 3$ v I. třídě. Po diskusi s vlastníkem tento prohlásil, že má k dispozici cihly, vápno i písek, takže když rozdělí prádelnu na dvě místnosti, bude zde i sušárna, kterou povedou stávající trubky topení, takže bude vytápěná, což by dalo další znak v I. trrídě, a že to provede do dalšího dne. Toto ovšem neprovedl, po prodeji navíc ještě odmontoval a odvezl zařizovací předměty z koupelny, radiátory, dokonce strhal i PVC z podlahy. Technik přebírající organizace objekt $\mathrm{v}$ tomto stavu odmítl převzít a podal trestní oznámení. Stíháni pak byli oba - znalec za nepravdivý znalecký posudek a spolu s původním vlastníkem i za rozkrádání majetku v socialistickém vlastnictví.9)

\subsubsection{Příklad ocenění objektu formálně rozděleného na dva RD}

Další prríklad, tentokrát z moravsko-slovenského pomezí. Dům ve spoluvlastnictví dvou manželských párů, o něco větší než rodinný, ocenil by se tedy jako stavba v soukromém vlastnictví za velmi nízkou cenu. Jeden ze spoluvlastníků (nezjištěno, jak to dokázal) nechal objekt čarou v katastrální mapě rozdělit na dva rodinné domy, na MNV mu bylo dokonce přiděleno další popisné číslo. Fyzicky ovšem dům rozdělen nebyl, měl nadále jen jedno schodiště, dělicí čára šla jeho středem. Následně spoluvlastníci provedli vypořádání, každý pár se stal spoluvlastníky jednoho čísla popisného, státní notáŕ smlouvy schválil a byly zaregistrovány v evidenci nemovitostí (tehdy místo katastru). Následně se dohodli se socialistickou organizací na odprodeji celého areálu. Dva znalci (tehdy při převodu mezi občanem a socialistickou organizací povinně dva) ocenili objekt jako dva zcela samostatné rodinné domy; v posudku skutečnost, že fyzicky se jedná o jeden objekt, neuvedli (zamlčeli tedy skutečnost důležitou pro rozhodnutí - viz trestný čin Křivá výpověd' a nepravdivý znalecký posudek).

Soud v první instanci nejprve řízení zastavil s tím, že znalci nepřísluší rozhodovat právní otázky; když notář schválil předcházející směnné smlouvy, tak vlastně legalizoval dva rodinné domky. Odvolací soud ovšem vyslovil jiný názor.

Za dobu šetření se změnila podmínka ocenění daného typu stavby; domy obdobné rodinným, s obytnou plochou větší než 120 $\mathrm{m}^{2}$ (do $180 \mathrm{~m}^{2}$ ) se ocenily, jakoby měly $120 \mathrm{~m}^{2}$. I tak rozdíl činil cca 12000 Kč; trestem pro znalce a organizujícího spoluvlastníka byl jeden rok odnětí svobody.

\subsection{Období oceňování staveb bodovací metodikou (1. 1. 1985} až 31. 10. 1994)

\subsubsection{Bodovací metodika}

Jedná se o období od 1. 1. 1985 do 31. 10. 1994, za platnosti metodicky podobných předpisů:

- vyhláška č. 128/1984 Sb., o cenách staveb, pozemků, porostů, úhradách za zrrízení práva osobního užívání

\footnotetext{
9) Na vypracování znaleckého posudku se podílela mj. i posluchačka kursu technického znalectví na ústavu. Po dokončení posudku následovalo projednávání obžaloby znalce u soudu, jíž se dotyčná zúčastnila; pod dojmem této trapné situace odmítla následně po úspěšném dokončení kursu dát se jmenovat znalkyní.
} 
pozemků a náhradách za dočasné užívání pozemků (+ redakční sdělení č. 33/1985 Sb., o opravě tiskových chyb ve vyhlášce č. 128/1984 Sb.), dále

- vyhláška č. 182/1988 Sb. s novelami č. 316/1990 Sb., č. 589/1990 Sb. a č. 40/1991 Sb., a konečně

- vyhláška č. 393/1991 Sb., s novelami č.110/1992 Sb. a č.611/1992 Sb., a

- výměr ministerstva financí ČR č. 9/16/1992, kterým se stanoví způsob zpracování cenových map pozemků.

Princip bodovací metodiky ocenění staveb byl následující:

- pro daný druh stavby (rodinný dům, rekreační chata atd.) byla vybrána typická velikost objektu co do velikosti zastavěné plochy (např. u rodinných domků $100 \mathrm{~m}^{2}$ ),

- pro jednotlivá materiálová provedení byla zjištěna cena jednotlivých konstrukcí resp. vybavení pro jedno podlaží,

- podílem ceny konstrukce za celé podlaží k zastavěné ploše podlaží byla zjištěna cena této konstrukce, připadající na jeden metr čtvereční zastavěné plochy podlaží,

- tyto ceny v Kčs pro různá provedení konstrukcí a vybavení byly seřazeny do tabulky pro daný typ objektu jako body, tabulky pak byly vydány jako prŕlohy vyhlášky (příklad viz zde tab. 2),
- při následném oceňování konkrétních staveb se při prohlídce objektu zjistila zastavěná plocha všech podlaži (požadovaná světlá výška alespoň v části místností min. 1,6 metru; z plochy podzemního podlaží a z plochy podkroví se počítalo jen $80 \%$ skutečné výměry),

- $\quad$ jednotlivých podlažích se zjistilo převažující provedení jednotlivých konstrukcí, následně se jim přidělil podle př́slušné př́ilohy vyhlášky odpovídající počet bodů (příklad v tab. 3),

- body za jednotlivá podlaží se sečetly, násobily zastavěnou plochou podlaží a cenou bodu (zpravidla $1 \mathrm{Kčs} /$ bod, jen jednou krátce $\mathrm{u}$ chat $1,30 \mathrm{Kčs} / \mathrm{bod})$,

- ceny jednotlivých podlaží se pak sečetly,

- následně se odečetlo opotřebení, jako dříve podle stáří zpravidla $1 \%$ ročně, nejvýše však $80 \%$,

- pokud byla známa nabývací cena po 1. 6. 1953 (datum měnové reformy), provedl se obdobný výpočet s touto nabývací cenou, následně se použila vyšší výsledná cena $\mathrm{z}$ obou (príklad v tab. 4).

\subsubsection{Př́iklady $k$ bodovací metodice}

Největší akcí k bodovací metodice byly na ústavu revizní posudky na nemovitosti, vykupované v souvislosti se zátopou vodní nádrží

Tab. 2 Přiklad tabulky počtu bodi̊ pro oceněni podlaži stavby podle vyhlášky č.182/1988 Sb. ve znění vyhl. č. 316/1990 Sb., č. 589/1990 Sb. a č. 40/1991 Sb.

Tab. 2 Example of a table of the number of points for the valuation of the floor of a building according to Decree No. 182/1988 Coll. as amended No. 316/1990 Coll., No. 589/1990 Coll. and No. 40/1991 Coll.

Př́iloha č. 3 vyhlášky - GARÁŽE A VEDLEJŠÍ STAVBY

\begin{tabular}{|c|c|c|}
\hline Znak č. & Konstrukce a vybavení & Počet bodů za $1 \mathrm{~m}^{2}$ \\
\hline \multirow[t]{3}{*}{1.} & Osazení do terénu v průměrné hloubce nad 1 m (jen u podzemního podlaží) & \\
\hline & a) se svislou izolací & 320 \\
\hline & b) bez svislé izolace & 140 \\
\hline \multirow[t]{5}{*}{2.} & Základy a podezdívka (uvažuje se jen u prvého nadzemního podlaží) & \\
\hline & 2.1. betonové, podezdívka cihelná nebo kamenná spárovaná nebo omítaná & 65 \\
\hline & 2.2. betonové, podezdívka rovněž betonová & 40 \\
\hline & 2.3. bez podezdívky, pouze základové pásy & 35 \\
\hline & 2.4. bez podezdívky, pouze základy pod sloupky & 25 \\
\hline \multirow[t]{6}{*}{3.} & Svislé konstrukce (mimo společných) & \\
\hline & 3.1. zděné o tl. $\min .45 \mathrm{~cm}$ & 490 \\
\hline & 3.2. zděné nebo betonové $\mathrm{s}$ tepelnou izolací, $\min$. tl. $30 \mathrm{~cm}$ & 445 \\
\hline & 3.3. zděné, betonové bez tepelné izolace, o tl. menší než $30 \mathrm{~cm}$ nebo dřevěné trámkové oboustranně obité & 390 \\
\hline & $\begin{array}{l}\text { 3.4. dřevěné trámkové jednostranně obité nebo kovová kostra či pilířky s dřevěným plechovým nebo } \\
\text { osinkocementovým opláštěním }\end{array}$ & 360 \\
\hline & 3.5. pouze pilíŕky & 185 \\
\hline \multirow[t]{7}{*}{4.} & Stropy & \\
\hline & 4.1. železobetonové nebo keramické s podhledem a s tepelnou izolací & 110 \\
\hline & 4.2. železobetonové nebo keramické bez tepelné izolace nebo klenuté do ocelových nosníků & 90 \\
\hline & 4.3. trámkové s podhledem & 80 \\
\hline & 4.4. trámkové bez podhledu & 70 \\
\hline & 4.5. plechové nebo osinkocementové na kovové kostře & 65 \\
\hline & 4.6. podbití krovu & 30 \\
\hline
\end{tabular}


Příloha č. 3 vyhlášky - GARÁŽE A VEDLEJŠÍ STAVBY (pokračování).

Znak ̌̌.

Konstrukce a vybavení

Počet bodů za $1 \mathrm{~m}^{2}$

5. Krov (započítává se v nadzemním podlaží s největší zastavěnou plochou)

5.1. umožňující zřízení podkroví

5.2. ostatní neumožňující zřízení podkroví

6. Krytina (započítává se v nadzemním podlaží s největší zastavěnou plochou)

6.1. plechová

a) z mědi

b) z hliníku

c) pozinkovaná

6.2. tašková nebo osinkocementové šablony

6.3. živičná svařovaná

6.4. lepenková nebo vlnité osinkocementové desky

7. Vnější úprava povrchů

7.1. břizolit

7.2. stříkaný břizolit, vápenná štuková omítka

7.3. vápenná hladká omítka, spárované zdivo

7.4. vápenná hrubá omítka nebo nátěr

40

7.5. napuštění impregnací

8. Vnitřní úprava povrchů

8.1. vápenná štuková omítka

8.2. vápenná hladká omítka

8.3. vápenná hrubá omítka

8.4. nátěry

8.5. napuštění impregnací

9. Kanalizace

9.1. napojení na kanalizační řád vč. lapače olejů a benzínu

9.2. napojení na kanalizaci nebo žumpu

9.3. odvodnění gulou před objektem do kanalizace

9.4. sběrná jímka nebo napojení objektu na trativod

10. Rozvod vody

10.1. studené a teplé z centrálního zdroje

10.2. jen studené

10.3. vodovodní kohout na vnějším líci zdi

11. Vytápění

11.1. ústřední

a) kotel ÚT (započít. se do největšího podlaží)

b) radiátory (za vytápěné podlaží)

11.2. lokální

a) akumulační za každý kus

b) naftové, na tuhá paliva stáložárná za každý kus

25

c) ostatní na tuhá paliva za každý kus

d) krb za každý kus

12. Elektroinstalace

12.1. světelná a motorová

12.2. světelná

12.3. provizorní 
Př́iloha č. 3 vyhlášky - GARÁžE A VEDLEJŠÍ STAVBY (pokračování).

Znak č.

Konstrukce a vybavení

Počet bodů za $1 \mathrm{~m}^{2}$

13. Okna

13.1. dvojitá

60

13.2. zdvojená

13.3. jednoduchá

14. Dveře

14.1. vstupní masivní, ostatní hladké do ocelových zárubní 30

14.2. hladké 25

14.3. náplňové, kovové $\quad 20$

14.4. svlakové, lat’ové $\quad 10$

15. Vrata

15.1. výklopná, dřevěná přírodní $\quad 85$

15.2. dřevěná nebo plechová natřená krycím nátěrem $\quad 55$

16. Podlahy

16.1. palubkové, lité teraco, stěrkové, keramická dlažba 95

16.2. prkenné, lepené podlahové povlaky, xylolit, dřevotříska 70

16.3. betonové s potěrem, teracové nebo cementové dlaždice 55

$\begin{array}{ll}\text { 16.4. hrubé betonové, cihelná dlažba } & 40\end{array}$

17. Klempírské konstrukce

17.1. z měděného plechu (min. žlaby, svody, oplechování kolem komínů a průniků) 230

17.2. z pozinkovaného plechu

a) úplné střechy (Žlaby, svody, komíny, průniky) $\quad 50$

$\begin{array}{ll}\text { b) jen žlaby a svody } & 25\end{array}$

$\begin{array}{ll}\text { c) parapety } & 5\end{array}$

18. Vnitřní vybavení (počítá se za každý kus)

18.1. elektrický boiler $\quad 60$

18.2. koupelnová kamna nebo kotel na prádlo na tuhá paliva 25

$\begin{array}{ll}\text { 18.3. vana, samostatná sprcha } & 30\end{array}$

$\begin{array}{lr}\text { 18.4. umyvadlo } & 5\end{array}$

$\begin{array}{lr}\text { 18.5. záchodová mísa } & 10\end{array}$

$\begin{array}{ll}\text { 18.6. elektrický nebo plynový sporák } & 40\end{array}$

18.7. uhelný sporák 15

$\begin{array}{lr}\text { 18.8. malý sporáček na uhlí } & 10\end{array}$

19. Schodiště

19.1. dřevěná konstrukce, schody s podstupnicemi $\quad 90$

19.2. dřevěná konstrukce, schody bez podstupnic $\quad 60$

$\begin{array}{ll}\text { 19.3. kovová konstrukce s jakýmikoliv stupni } & 50\end{array}$

19.4. betonové nebo cihelné $\quad 70$

20. Okenice $\quad 50$

21. Mříze 40

22. Sauna 240

Počet bodů pro jednotlivé konstrukce a vybavení je neměnný.

Pokud se některé znaky na objektu nevyskytují, činí počet bodů pro tyto znaky 0 .

Počet znaků nesmí být rozšiřován.

Pokud se některé konstrukce a vybavení vyskytují na objektu v jiném provedení, ohodnotí se počtem bodů podle nejbližšího porovnatelného provedení.

Počet bodů jednotlivých znaků se stanoví podle převažujícího provedení. 
Tab. 3 Jednopodlažni vedlejši stavba - ohodnoceni bodovaci metodikou podle přilohy č. 3 vyhlášky č. 182/1988 Sb., ve zněni vyhlášky č. $316 / 1990 \mathrm{Sb}$.

Tab. 3 One-storey ancillary building - evaluation by scoring methodology according to Annex No. 3 of Decree No. 182/1988 Coll., as amended by Decree No. 316/1990 Coll.

\begin{tabular}{|c|c|c|c|c|c|c|}
\hline \multirow{2}{*}{ Znak č. } & 1. nadzemní podlaží (1.NP) & \multirow{2}{*}{$\begin{array}{l}\text { Počet bodů } \\
\text { za } 1 \text { m }^{2}\end{array}$} & \multirow{2}{*}{$\begin{array}{c}\text { Počet } \\
\text { položek }\end{array}$} & \multirow{2}{*}{$\begin{array}{l}\text { Počet } \\
\text { bodů }\end{array}$} & \multirow{2}{*}{$\begin{array}{c}\text { Dokonč. } \\
\%\end{array}$} & \multirow{2}{*}{$\begin{array}{l}\text { Počet } \\
\text { bodů }\end{array}$} \\
\hline & Konstrukce a vybavení & & & & & \\
\hline 1. & Osazení do terénu v průměrné hloubce nad $1 \mathrm{~m}$ & není & & & & 0 \\
\hline \multirow[t]{2}{*}{2.} & Základy a podezdívka & & & & & \\
\hline & 2.3. bez podezdívky, pouze základové pasy & 35 & 1 & 35 & 100 & 35 \\
\hline \multirow[t]{2}{*}{3.} & Svislé konstrukce (mimo společných) & & & & & \\
\hline & 3.3. zděné, bez tepelné izolace, o tl. menší než $30 \mathrm{~cm}$ & 390 & 1 & 390 & 100 & 390 \\
\hline \multirow[t]{2}{*}{4.} & Stropy & & & & & \\
\hline & 4.4. trámkové bez podhledu & 70 & 1 & 70 & 100 & 70 \\
\hline \multirow[t]{2}{*}{5.} & Krov & & & & & \\
\hline & 5.1. umožňující zřízení podkroví & 50 & 1 & 50 & 100 & 50 \\
\hline \multirow[t]{2}{*}{6.} & Krytina & & & & & \\
\hline & 6.2. tašková & 60 & 1 & 60 & 100 & 60 \\
\hline \multirow[t]{2}{*}{7.} & Vnější úprava povrchů & & & & & \\
\hline & 7.3. vápenná hladká omítka & 50 & 1 & 50 & 100 & 50 \\
\hline \multirow[t]{2}{*}{8.} & Vnitřní úprava povrchů & & & & & \\
\hline & 8.3. vápenná hrubá omítka & 0 & 1 & 0 & 100 & 0 \\
\hline \multirow[t]{2}{*}{9.} & Kanalizace & & & & & \\
\hline & 9.2. napojení na žumpu & 60 & 1 & 60 & 100 & 60 \\
\hline 10. & Rozvod vody & není & & & & 0 \\
\hline 11. & Vytápění & není & & & & 0 \\
\hline \multirow[t]{2}{*}{12.} & Elektroinstalace & & & & & \\
\hline & 12.2. světelná & 40 & 1 & 40 & 100 & 40 \\
\hline \multirow[t]{2}{*}{13.} & Okna & & & & & \\
\hline & 13.3. jednoduchá & 25 & 1 & 25 & 100 & 25 \\
\hline \multirow[t]{2}{*}{14.} & Dveře & & & & & \\
\hline & 14.4. svlakové & 10 & 1 & 10 & 100 & 10 \\
\hline 15. & Vrata & nejsou & & & & 0 \\
\hline \multirow[t]{2}{*}{16.} & Podlahy & & & & & \\
\hline & 16.4. hrubé betonové, cihelná dlažba & 40 & 1 & 40 & 100 & 40 \\
\hline \multirow[t]{4}{*}{17.} & Klempírské konstrukce & & & & & \\
\hline & 17.2. z pozinkovaného plechu & & & & & \\
\hline & b) žlaby a svody & 25 & 1 & 25 & 100 & 25 \\
\hline & c) parapety & 5 & 1 & 5 & 100 & 5 \\
\hline 18. & Vnitřní vybavení (počítá se za každý kus) & není & & & & 0 \\
\hline 19. & Schodiště & není & & & & 0 \\
\hline 20. & Okenice & nejsou & & & & 0 \\
\hline 21. & Mříže & nejsou & & & & 0 \\
\hline 22. & Sauna & není & & & & 0 \\
\hline Celkem & 1. nadzemní podlaží (1.NP) & & bodů & 860 & & 860 \\
\hline
\end{tabular}

Slezská Harta na řece Moravici v okrese Bruntál. Stavba byla zahájena v roce 1987 a dokončena $v$ roce 1997. Podle rozlohy je devátou největší v České republice. Voda přehrady zatopila z části celkem 6 vesnic. Částečně byly zatopeny obce Nová Pláň, Razová, Dlouhá Stráň, Leskovec a Roudno. Téměř zcela byl zatopen Karlovec, z něhož zůstal zachován pouze kostel sv. Jana
Nepomuckého. Jednalo se o území, jež náleželo k Sudetám, odkud byli po II. světové válce vysídleni němečtí obyvatelé a do staveb se prristěhovali dosídlenci z vnitrozemí. ${ }^{10)}$

10) Zajímavý zážitek autora: Když posluchači ohledávali jednu zemědělskou usedlost, seděl autor s vlastníkem na lavičce pobližz. Najednou vlastník 
Tab. 4 Jednopodlažni vedlejši stavba - oceněni při použití bodovaci metodiky podle vyhlášky č. 182/1988 Sb., ve znění vyhlášky c. $316 / 1990 \mathrm{Sb}$.

č. 182/1988 Sb., ve znění vyhlášky č. 316/1990 Sb.

Tab. 4 One-storey ancillary building - valuation using the scoring methodology according to Decree No. 182/1988 Coll., as amended by Decree No. 316/1990 Coll.

\begin{tabular}{|c|c|c|c|c|c|c|}
\hline Podlaží & $\begin{array}{l}\text { Zastavěná plocha } \\
\text { m }^{2}\end{array}$ & $\begin{array}{c}\text { Koeficient } \\
(\text { PP a podkroví }=0,8)\end{array}$ & $\begin{array}{l}\text { Plocha pro ocenění } \\
\text { m }^{2}\end{array}$ & $\begin{array}{l}\text { Počet bodů } \\
\text { na } 1 \text { m²}^{2}\end{array}$ & $\begin{array}{l}\text { Cena bodu } \\
\text { Kčs/b }\end{array}$ & $\begin{array}{c}\text { Cena podlaží } \\
\text { Kčs } \\
\text { (ev. rok) }\end{array}$ \\
\hline 1.PP & 0,00 & 0,80 & 0,00 & 6090 & 1,00 & 0,00 \\
\hline 1.NP & 36,00 & 1,00 & 36,00 & 860 & 1,00 & 30960,00 \\
\hline 2.NP & 0,00 & 1,00 & 0,00 & 6540 & 1,00 & 0,00 \\
\hline \multicolumn{3}{|c|}{ Celkem výchozí cena } & & & & 30960,00 \\
\hline \multicolumn{3}{|c|}{ Rok začátku užívání } & & & rok & 1965 \\
\hline \multicolumn{3}{|c|}{ Rok odhadu } & & & rok & 1990 \\
\hline \multicolumn{3}{|c|}{ Stáří } & & & roků & 25 \\
\hline \multicolumn{3}{|c|}{ Předpokládaná životnost } & & & roků & 80 \\
\hline \multicolumn{3}{|c|}{ Roční procento opotřebení } & & & $\% / \mathrm{r}$ & 1,25 \\
\hline \multicolumn{3}{|c|}{ Opotřebení v procentech $(\max .85 \%)$} & & & $\%$ & 31,25 \\
\hline \multicolumn{3}{|c|}{ Opotřebení v Kčs } & & & Kčs & $-9675,00$ \\
\hline \multicolumn{5}{|c|}{ Cena dle bodovací metodiky po odpočtu opotřebení } & Kěs & 21285,00 \\
\hline \multicolumn{5}{|c|}{ Cena, za kterou byla stavba prokazatelně nabyta po 1. 6. $1953(\S 20)$} & Kčs & 40000,00 \\
\hline \multicolumn{5}{|c|}{ Rok nabytí za tuto cenu ( $v$ daném prípadě náklady na novostavbu) } & & 1965 \\
\hline \multicolumn{3}{|c|}{ Počet roků od nabytí } & & & roků & 25 \\
\hline \multicolumn{3}{|c|}{ Roční procento opotřebení } & & & $\% / \mathrm{r}$ & 1,25 \\
\hline \multicolumn{3}{|c|}{ Opotřebení z nabývací ceny } & & & $\%$ & 31,25 \\
\hline \multicolumn{3}{|c|}{ Odpočet opotřebení z nabývací ceny } & & & Kčs & $-12500,00$ \\
\hline \multicolumn{3}{|c|}{ Nabývací cena po odpočtu opotřebení } & & & Ǩ̌s & 27500,00 \\
\hline \multicolumn{3}{|c|}{ Cena ke dni odhadu } & & & Ǩ̌s & 27500,00 \\
\hline
\end{tabular}

Celkem bylo odstraněno 300 budov. Stávající vlastníci dostali finanční odškodnění a byli přesídleni do částí obcí nad vodou nebo do panelových domů v nedalekém Bruntále. ${ }^{11)}$ Pro ocenění byli sezváni znalci celého kraje s poučením, jak mají ocenění provádět, údajně s připomenutím, že opotřebení staveb má být vždy $1 \%$ za rok stáří až do maximální meze $80 \%$. Vlastnící byli většinou spokojeni, někteří se již těšili do nového, prŕípadně ze starého domku do nového bytu, zejména lidé ve vyšším věku. Jen asi deset vlastníků nebylo spokojeno; v těchto př́padech pak byl ÚSI VUT v Brně požádán o posudky revizní. V dalším jsou uvedeny poučné zkušenosti, získané při jejich provádění, včetně prohlídky objektů za účasti vlastníků a zástupců objednatele posudků.

Jedním z takovýchto poznatků bylo problematické ohledání původními znalci. $\mathrm{V}$ jednom př́padě jsme na vlastníky vznesli dotaz, co se jim na původním posudku nelíbilo. Odpověd' byla v tom smyslu, že znalkyně tam byla jen asi čtvrt hodiny, na zahradu se pak přijela podívat jindy, ale jen ze silnice, takže to snad nemůže být dobře. V jiném případě, když vlastník, jenž

upozorňoval, že právě zaměřovaný chlév je mladší, postavil jej předchozí vlastník - Němec - za války. Na dotaz, jak to ví, když Němci byli odsunuti, reagoval: „Ono to nějakou dobu trvalo, než je odsunuli, a tak jsem tady s ním sedával na lavičce a povídali jsme si, jako ted', než odsunou mne, tu sedím a povídám si s vámi.“

11) Více viz např. https://cs.m.wikipedia.org/wiki/Vodní_nádrž_Slezská_Harta. byl povoláním zedník, nemovitost velmi dobře udržoval, chtěl znalci ukázat všechna potvrzení na zakoupený materiál na údržbu, znalec prohlásil, že jej to nezajímá a že za pưl hodiny musí být jinde. Ohledání mu údajně trvalo hodinu, přitom areál byl natolik rozsáhlý, že v rámci posudku jej ohledávali tři stavební inženýři frekventanti kursů soudního znalectví - více než půl dne.

Specifický byl př́pad jednoho dvojdomku, kdy každá polovina měla vlastní vchod, svoje popisné číslo, svůj stavební pozemek a dokola zahradu. Po př́jezdu na místo posluchači stáli před brankou, studovali podklady a ne a ne jít dovnitř. Na dotaz autora sdělili, že podle grafického podkladu jsou domky podle popisného čísla ve vztahu k pozemkům obráceně; přitom u jednoho již výkup proběhl. Předchozí znalec ani nikdo jiný si nevšiml toho, že vlastně obě rodiny dosídlenců bydlely celá léta v polovině dvojdomku, jež patřila druhé rodině.

Hlavním problémem ale byla problematika opotřebení. Jednalo se vesměs o starší stavby, předválečné, po válce obydlené dosídlenci. $\mathrm{S}$ ohledem na plánovanou vodní nádrž zde již delší dobu byla stavební uzávěra, stavby byly proto různě udržované (o výstavbě se začalo uvažovat už v 60. letech 20. století, kvưli zvětšujícím se požadavkům na vodu ze strany průmyslu a obyvatel ve Slezsku a na severní Moravě). Bylo proto původními znalci uvažováno opotřebení staveb $1 \%$ za rok stáŕí, až do max. $80 \%$. Vlastníci, kteří stavbu dobře udržovali, ovšem nesouhlasili s tím, že stavby by měly mít hodnotu jenom zbytkových $20 \%$. V revizních 
posudcích byl zohledněn stav jednotlivých konstrukcí a bylo propočteno opotřebení, odpovídající skutečnému fyzickému stavu a předpokládané životnosti za předpokladu běžné preventivní údržby. ${ }^{12)}$

\subsection{Oceňování při převodech na československou právnickou osobu se zahraniční účastí}

Po změně poměrů byla vydána s obdobnou metodikou vyhláška č. 393/1991 Sb., o cenách staveb, pozemků, trvalých porostů, úhradách za zřízení práva osobního užívání pozemků a náhradách za dočasné užíání pozemků, následně s novelami č. 110/1992 Sb. a č. 611/1992 Sb. Dále byl vydán výměr ministerstva financí ČR č. 9/16/1992, kterým se stanoví způsob zpracování cenových map pozemků.

Nově zde byl stanoven způsob stanovení ceny staveb, pozemků a trvalých porostů prri převodech na československou právnickou osobu se zahraniční účastí nebo na zahraniční právnickou osobu; cena se vypočetla $\mathrm{v}$ cenové úrovni zahraničního trhu na základě technického ohodnocení podle metodiky něžné v zahraničí (SRN,

12) V sousvislosti s tím se autorovi vybavuje smutný příběh. V jedné z obcí byly vedle sebe dva domky, prakticky stejné, ve stejném stavu. Jedna majitelka souhlasila se zbytkovými $20 \%$; sousedé se ale odvolali a vzhledem k velmi dobrému stavu vyšlo opotřebení $60 \%$, tedy zbytkových $40 \%$, což je ovšem dvojnásobek toho, co dostala prvně jmenovaná vlastnice. Ta, když se to dozvěděla, si sáhla na život.
Rakousko) a přepočetla se na čs. měnu platným kurzem ke dni zpracování ocenění; cena byla platná až po schválení ministerstvem financí, Sjednat bylo možno i cenu odlišnou. Cena takto vycházela několikanásobně vyšší než podle české metodiky. ${ }^{13)}$

\subsection{Oceňování pro malou privatizaci}

Další novinkou vyhlášky byla metodika stanovení vyvolávací ceny pro veřejné dražby majetku státu $\mathrm{v}$ rámci tzv. malé privatizace (zákon č. 427/1990 Sb. ve znění zákona č. 541/1990 Sb.). Cena se stanovila z pořizovací ceny stavby $\mathrm{v}$ době jejího vzniku, násobené indexem podle tabulky vyhlášky (zde viz tab. 5, v ní tabulka č. 1). Vyvolávací cena stavby se pak rovnala takto zjištěné ceně stavby, upravené koeficientem uvedeným v tabulce č. 2. Cena pozemků pro tuto dražbu se neregulovala; při určení vyvolávací ceny pozemku se přihlíželo zejména k velikosti a významu obce, druhu stavebního pozemku, obchodní a průmyslové poloze, prŕístupnosti a infrastruktuře, př́ípadně dalším zvláštním podmínkám, které mohly mít vliv na výši ceny.

\footnotetext{
13) Toto mělo i negativní důsledky; určitý čas platilo, že pokud někdo koup nemovitost za cenu nižší než zjišsěnou, rozdíl je vlastně darem a podléhá tudíž dani darovací. Důsledkem byl případ, kdy dlouho bezúspěšně nabízenou halu konečně koupila společnost se zahraniční majetkovou účastí za 1 milion Kč. Odhad podle německé metodiky ovšem vyšel kolem 5 milionů Kč, vzhledem k tomu byla kupci doměřena vysoká darovací dan̆ $\mathrm{z}$ rozdílu 4 miliony $\mathrm{Kč}$.
}

Tab. 5 Indexy a koeficienty pro úpravu pořizovací ceny stavby pro účely privatizace podle vyhlášky č. 393/1991 Sb.

Tab. 5 Indices and coefficients for adjusting the acquisition price of a building for the purposes of privatization pursuant to Decree No. 393/1991 Coll.

\begin{tabular}{llll}
\hline \multicolumn{4}{c}{ Tabulka č. 1 } \\
\hline $\begin{array}{c}\text { Pořizovací cena v cenové } \\
\text { úrovni }\end{array}$ & Index & $\begin{array}{c}\text { Pořizovací cena v cenové } \\
\text { úrovni }\end{array}$ & Index \\
\hline do 20. 6. 1939 & 4,00 & $1.1 .1967-31.12 .1969$ & 3,20 \\
20. 6. 1939-31. 12. 1942 & 2,27 & $1.1 .1970-31.12 .1976$ & 4,16 \\
1. 1. 1943-31. 12. 1945 & 1,99 & $1.1 .1977-31.12 .1981$ & 4,09 \\
$1.1 .1946-31.12 .1951$ & 0,93 & $1.1 .1982-31.12 .1984$ & 2,63 \\
$1.1 .1952-31.5 .1953$ & 0,74 & $1.1 .1985-31.12 .1988$ & 2,35 \\
$1.6 .1953-30.6 .1959$ & 3,82 & $1.1 .1989-31.12 .1989$ & 2,27 \\
$1.7 .1959-31.3 .1964$ & 4,49 & $1.1 .1990-31.12 .1990$ & 2,12 \\
$1.4 .1964-31.12 .1966$ & 4,79 & 1.1 .1991 a dále & 1,00 \\
\hline
\end{tabular}

\begin{tabular}{cc}
\hline \multicolumn{2}{c}{ Tabulka č. 2 } \\
\hline Stavba z roku & Koeficient \\
\hline do r. 1930 & 0,25 \\
1931 až 1940 & 0,40 \\
1941 až 1950 & 0,50 \\
1951 až 1960 & 0,60 \\
1961 až 1970 & 0,70 \\
1971 až 1980 & 0,85 \\
1981 a dále & 0,95 \\
\hline
\end{tabular}

Tab. 6 Historický přehled predpisů pro oceňování nemovitostí.

Tab. 6 Historical overview of regulations for real estate valuation.

\section{Do roku 1933}

Nařizení ministerstva spravedlnosti č. 175/1897 ř.z. (odhadní řád)

Patent ze dne 9. srpna 1854 ř. z. č. 208, týkající se soudních odhadů.

Období 1933-1939

Vládní nařízení č. 100/1933 Sb. z. a n., kterým se vydávají předpisy o odhadu nemovitostí v řízení exekučním (odhadní řád)

Období 1939-1950

Nařízení předsedy vlády č. 175 ze dne 20. 7. 1939, o zákazu zvýšení cen (platilo např. pro převody staveb mezi občany na území ČR u staveb v osobním vlastnictví, postavených do 20. 6. 1939, do nabytí účinnosti vyhl. č. 73/1964 Sb., u pozemků do výměru č. 120/47/79, u trvalých porostů do výměru č. 315/126/78, u staveb v soukromém vlastnictví postavených do 20. 6. 1939 až do nabytí účinnosti vyhlášky č. 128/1984 Sb.)

\section{Období 1944-1950}

Zákon č. 134/1946 Sb., o dávce z majetkového př́růstku a o dávce z majetku

Vládní nařízení č. 106/1947 Sb., o přídělu drobných konfiskovaných živnostenských podniků (přídělové nařízení pro živnostenské podniky)

Vyhláška č. 140/1947 Ú.1., o nejvyšších cenách za upotřebené zboží

Zákon č. 142/1947 Sb., o revisi první pozemkové reformy

Vládní nařízení č. 163/1947 Sb., o přídělu konfiskovaných rodinných domků (přídělové nařízení pro rodinné domky)

Vyhláška č. 97/1949 Sb., o úplném znění př́ídělového nařízení pro rodinné domky 


\section{Období 1951-1964}

Zákon č. 41/1953 Sb., o peněžní reformě (jen oddíl II, § 4)

Směrnice ministerstva financí o generální inventarizaci, publikované v částce 43 Úředního listu ročník 1954

Vyhláška č. 18/1963 Sb., o stanovení náhrady za vyvlastnění nemovitostí občanům a soukromým právnickým osobám

\section{Období 1964-1984}

Vyhláška č. 73/1964 Sb., o cenách staveb v osobním vlastnictví a o náhradách při vyvlastnění nemovitostí

Vyhláška č. 43/1969 Sb., o cenách staveb v osobním vlastnictví a o náhradách při vyvlastnění nemovitostí

Vysvětlivky ČCÚ a MF ČR k vyhlášce č. 43/1969 Sb. z roku 1970 (čj. ČCÚ:1090/70/Ing.Hor./H, MF:314/6.472/70)

Vysvětlivky ČCÚ a MF ČR k některým ustanovením vyhlášky č. 43/1969 Sb. z roku 1980 (čj. ČCÚ: 23-520/80, MF:314/13 709/80)

Výměr č. 315/126/78 o cenách porostů (platný od 1. 6. 1978)

Výměr č. 120/47/79 o cenách pozemků (platný od 1. 4. 1979)

Výměr č. $982 / 80$ o rozšíření platnosti výměru č. 120/47/79 o cenách pozemků

Metodická pomůcka pro oceňování pozemků podle výměru ČCÚ a SCÚ č. 120/47/79

\section{Období 1985-1987}

Vyhláška č. 128/1984 Sb., o cenách staveb, pozemků, porostů, úhradách za zrízení práva osobního uživání pozemků a náhradách za dočasné užívání pozemků Redakční sdělení č. 33/1985 Sb., o opravě tiskových chyb ve vyhlášce č. 128/1984 Sb.

Miloslav Milota, Jak ocenit nemovitost (př́iloha Hospodářských novin č. 2/1986 - české vydání)

Období 1988-1990

Vyhláška č. 182/1988 Sb., o cenách staveb, pozemků, trvalých porostů, úhradách za zřízení práva osobního užívání pozemků a náhradách za dočasné užívání pozemků

Novely: vyhláška č. 316/1990 Sb., č. 589/1990 Sb., č. 40/1991 Sb.,

Období 1991-1994

Vyhláška č. 393/1991 Sb., o cenách staveb, pozemků, trvalých porostů, úhradách za zřízení práva osobního užívání pozemků a náhradách za dočasné užívání pozemků

Novely: vyhláška č.110/1992 Sb., č.611/1992 Sb.

Zákon ČNR č. 367/1990 Sb., o obcích, § 3 (statutární města v ČR)

Výměr ministerstva financí ČR č. 9/16/1992, kterým se stanoví způsob zpracování cenových map pozemků.

\section{Období od 1. 11. 1994 do 31. 12. 1997}

Vyhláška č. 178/1994 Sb., o oceňování staveb, pozemků a trvalých porostů

Od 1. 1. 1996 změna vyhláškou č. 295/1995 Sb.

\section{Období od 1. 1. 1998}

Zákon č. 151/1997 Sb., o oceňování majetku a o změně některých zákonů (zákon o oceňování majetku), ve znění zákona č. 121/2000 Sb., č. 237/2004 Sb., č. 257/2004 Sb., č. 296/2007 Sb., č. 188/2011 Sb., č. 350/2012 Sb. č. 303/2013 Sb. zákonného opatření Senátu č. 340/2013 Sb. a č. 344/2013 Sb. (rovněž zrušena část šestá), zákona č. 228/2014 Sb., č. 225/2017 Sb. a č. 237/2020 Sb. (zaveden nový termín tržní hodnota)

Vyhláška č. 279/1997 Sb., k provedení některých ustanovení zákona č. 151/1997 Sb., o oceňování majetku a o změně některých zákonů (zákon o oceňování majetku); novely: č. 127/1999 Sb. (od 1. 7. 1999), č. 173/2000 Sb. (od 1. 7. 2000), č. 338/2001 Sb. (od 1. 10. 2001), č. 325/2002 Sb. (od 19. 7. 2002).

Od 1. 1. 2003 vyhláška č. 540/2002 Sb., kterou se provádějí některá ustanovení zákona č. 151/1997 Sb., o oceňování majetku a o změně některých zákonů (zákon o oceňování majetku); novely: č. 452/2003 Sb. (od 1. 1. 2004), č. 640/2004 Sb. (od 1. 1. 2005), č. 617/2006 Sb. (od 1. 1. 2007).

Od 1. 2. 2008 vyhláška č. 3/2008 Sb., o provedení některých ustanovení zákona č. 151/1997 Sb., o oceňování majetku a o změně některých zákonů, ve znění pozdějších předpisů (oceňovací vyhláška).

Novely č. 456/2008 Sb. (od 1. 1. 2009), č. 460/2009 Sb. (od 1. 1. 2010), č. 364/2010 Sb. (od 1. 1. 2011), č. 387/2011 Sb. (od 1. 1. 2012), č. 450/2012 Sb. (od 1. ledna 2013)

Od 1. 1. 2014 vyhláška č. 441/2013 Sb., k provedení zákona o oceňování majetku (oceňovací vyhláška)

Novely č. 199/2014 Sb. (od 1. 10. 2014), č. 345/2015 Sb. (od 1. 1. 2016), č. 53/2016 Sb., č. 443/2016 Sb., č. 457/2017 Sb., č. 188/2019 Sb. a novela č. 488/2000 k 112021 .

\section{Správná citace:}

BRADÁČ, A. Z historie Ústavu soudního inženýrství Vysokého učení technického v Brně - IV. Soudní inženýrství, 2020, 31(4), 34-48. DOI: http://dx.doi.org./10.13164/SI.2020.4.34. ISSN 1211-443X. 